$A D D I N$, Volume 12, Number 1, February 2018

\title{
THE CHALLENGE OF ISLAM
}

NUSANTARA AGAINST TERORISM:

\section{Analysis Study of Islamic Nusantara of Ulama NU Movement in Central Java}

\section{Ma'mun Mu'min}

Institut Agama Islam Negeri (IAIN) Kudus, Central Java, Indonesia mukminmakmun@stainkudus.ac.id

\section{Fathul Mufid}

Institut Agama Islam Negeri (IAIN) Kudus, Central Java, Indonesia fathulmufid@stainkudus.ac.id

\section{Abstract}

The more widespread ideology in the era of global terrorism today has become a global concern, acts of terror committed national or transnational terrorists have been bad for the creation of a harmonious world order, pluralist and inclusive. Several countries collapse in the Middle East and Africa as well as the tense conditions in Poso has been the evidence of how acts of terror committed the terrorists do not recognize tribes, nations and religions. If this trend continues, then the life of mankind and civilization of the world will be damaged. Long before understanding terrorism rampant in Indonesia and the world, the scholars Walisongo through propaganda Islamiyah has offered the concept of Islam Nusantara, the moderate Islam that can adapt to the cultural heritage at the time. Islam Nusantara or moderate 
Islam is essentially Islam that gave mercy to all the worlds. These efforts Walisongo scholars ulama NU followed by the next generation until now. Rampant ideology of terrorism today is of course a challenge for the NU clerics spearbeading the development of Islam in the Indonesian archipelago. This research will find: formulation of basic normatively and historicity and the philosophical concept of Islam Nusantara, formulated the concept of Islam Nusantara in the perspective of scholars Walisongo and ulama NU in Central Java, the dynamics of socio-political development of Islam Nusantara in Central Java from time to time, the public response in Central Java to the development of Islam Nusantara, and the contribution of Islam Nusantara in a moderate Islam that can create harmony, pluralist and inclusive in order peaceful world civilization.

Keywords: Islam Nusantara, Terrorism, Ideology, Ulama, Social Movement.

\section{Abstrak}

TANTANGAN ISLAM NUSANTARA TERHADAP TERORISME: ANALISIS STUDI GERAKAN ISLAM NUSANTARA ULAMA NU DI JAWA TENGAH. Ideologi yang lebih luas di era terorisme global saat ini telah menjadi perbatian global, aksi teror yang dilakukan teroris nasional atan transnasional telah berdampak buruk bagi terciptanya tatanan dunia yang harmonis, pluralis, dan inklusif. Beberapa negara runtub di Timur Tengah dan Afrika serta kondisi tegang di Poso telah menjadi bukti bagaimana aksi teror yang dilakukan para teroris tidak mengakui suku, bangsa, dan agama. Jika kecenderungan ini berlanjut, maka kehidupan umat manusia dan peradaban dunia akan rusak. Jauh sebelum memahami terorisme merajalela di Indonesia dan dunia, para ulama Walisongo melalui propaganda Islamiyah telah menawarkan konsep Islam Nusantara, Islam moderat yang dapat beradaptasi dengan warisan budaya pada saat itu. Islam Nusantara atau Islam moderat pada dasarnya adalah Islam yang memberikan rahmat bagi semua dunia. Upaya ulama Walisongo ini diikuti 
oleh generasi berikutnya hingga sekarang. Ideologi terorisme yang merajalela saat ini tentu saja merupakan tantangan bagi para ulama NU yang mempelopori perkembangan Islam di Indonesia. Kajian ini telah merumuskan beberapa temuan sebagai berikut: perumusan normatif dan historisitas dasar dan konsep filosofis Islam Nusantara, merumuskan konsep Islam Nusantara dalam perspektif sarjana Walisongo dan ulama NU di Jawa Tengah, dinamika perkembangan sosial-politik Islam Nusantara di Jawa Tengah dari waktu ke waktu, respons masyarakat Jawa Tengah terhadap perkembangan Islam Nusantara, dan kontribusi pandangan Islam moderat Islam Nusantara yang dapat menciptakan harmoni, pluralis, dan inklusif dalam rangka peradaban dunia yang damai.

Kata Kunci: Islam Nusantara, Terorisme, Ideologi, Ulama, Gerakan Sosial.

\section{A. Introduction}

The historians agree that the first Islamic Nusantara was formed by the Walisongo. ${ }^{1}$ The name Walisongo was derived from the Arabic "waliyun tsanaun" mean the noble or choice guardian. This name was given by Sultan Mehmed I Sulaeman Celebi (1402-1411) from Turkey in 1404, for nine multitalented scholars were sent to Java for da'wah Islamiyah. They were: (1) Maulana Malik Ibrahim (d.1419) from Persia, the state expert; (2) Maulana Ishak (14 ${ }^{\text {th }}$ century) from Samarkand, the physician; (3) Maulana Ahmad Jumadil Kubra (born 1376) from Egypt, the master of debating; (4) Maulana Muhammad al-Maghribi (1310-1453) of Morocco, an orator; (5) Maulana Malik Israil $\left(14^{\text {th }}\right.$ century) from Turkey, the expert of the state; (6) Maulana

${ }^{1}$ See J.J. Meinsma, Serat Babad Tanah Jawi: Wiwit Saking Nabi Adam Dumugi Ing Tabun 1647 (n.p.: S'Gravenhage, 1903); Hamid Akasah and Aby Azizy (ed.), Babad Tanah Jawa: Majapahit, Demak, dan Pajang (Surabaya: Cipta Adi Grafika, 1989); A.R. Kapanjani, Menyingkap Kisab Keteladanan Perjuangan Walisongo (Surabaya: Anugerah, 1992); H.J. de Graff, et al., Cina Muslim di Jawa Abad XV dan XVI (Yogyakarta: Tiara Wacana, 2004). According to Agus Sunyoto, Maulana Malik Ibrahim came early in $1371 \mathrm{M}$ to Sembalo Manyar Gresik. See Agus Sunyoto, Atlas Walisongo (Jakarta: Pustaka Imam, 2012), 51. 
Muhammad Ali Akbar (14 $4^{\text {th }}$ century) from Persian Iran, wisdom expert and physician; (7) Maulana Hasanuddin (14 $4^{\text {th }}$ century) from Palestine, an orator; (8) Maulana Alayuddin (14 ${ }^{\text {th }}$ century) from Palestine, arguing expert; (9) Syekh Subakir (14 ${ }^{\text {th }}$ century) from Persia, bruise experts (bekam), geologists, ecologists, and land. These scholars set out and started Islamic preaching on Java island in $808 \mathrm{H}$ or $1404 \mathrm{AD}^{2}$

Arriving on Java, Walisongo assembled their respective areas in accordance with the situation and conditions of da'wah, such as Maulana Malik Ibrahim (died 1419), Raden Rahmat (1401-1481), Sunan Drajat (1470-1522), Sunan Giri (1442-1506), and Sunan Bonang (1465-1525) preaching in Surabaya, Gresik, Lamongan, and Tuban in East Java. Syekh Ja'far Shadiq (died 1550), Raden Said (born 1450), and Raden Umar Said (16 $6^{\text {th }}$ century) preached in Semarang, Demak, Kudus, Jepara, Pati, Blora, and Rembang in Central Java. Syarif Hidayatullah (1450-1569) and Maulana Hasanuddin (king of Banten 1552-1670) preaching in Cirebon and Banten in West Java. ${ }^{3}$ Theirnames were changed referred to place of their da'wah, such as Syekh Ja'far Shadiq (died 1550) called Sunan Kudus, Raden Umar Said (16 ${ }^{\text {th }}$ century) called Sunan Muria, ${ }^{4}$ and Raden Maulana Makdum Ibrahim (1465-1525) called Sunan Bonang.

Originally their da'wah mission centered along the northern coast of Java (Pantura) and hinterland of Majapahit (1293-1500), Pajajaran Kingdom (1030-1579), and Hindu

${ }^{2}$ See L.W.C. van den Berg, Le Hadbramout at les Colonies ArabesdansI'archipeiIndien (Batavia: Impr du Gouvement, 1886); J.J. Meinsma, Serat Babad Tanah Jawi: Wiwit Saking Nabi Adam Dumugi Ing Tabun 1647 (n.p.: S'Gravenhage, 1903); Zainal Abidin bin Syamsuddin, Fakta Baru Walisongo (Jakarta: Pustaka Imam Bonjol, 2016).

${ }^{3}$ Slamet Muljana, Runtubnya Kerajaan Hindu Jawa dan Timbulnya Negara-negara Islam di Nusantara (Yogyakarta: LKiS, 2015), 11-15; Hasan Muarif Ambary, Jacques Dumarcay, The Sultanate of Banten (Jakarta: Gramedia, 1990).

${ }^{4}$ See Rachmad Abdullah, Walisongo: Gelora Dakwah dan Jihad di Tanah Jawa (14041482 M) (Solo: Penerbit Al-Wafi, 2015). 
Buddhist communities. The da'wah area extended to Madura, Sumatra, Kalimantan, Sulawesi, Maluku, and reached Malaysia, Philippines, Thailand, Singapore, Vietnam, and Brunei Darussalam. ${ }^{5}$

Van den Berg's research (1884-1886) ${ }^{6}$ concluded that Walisongo's preaching was conducted peacefully. There is acculturation of Islamic culture with Java so the presence of Islam is easily accepted by the Hindu and Buddhist Javanese community. ${ }^{7}$ Orientalists accuse da'wah was carried out by force and sword, as alleged Golda Meil Teacher (1896-1978) from Israel and Samuel Marinus Zwimer (1867-1952) an American, was certainly not true. According to De Lacy O'Leary (1872-1957) from University of Bristol said, "The accusation that Islamwas spread with sword and violence only a myth, because the fact Islam is spread in peaceful and hospitable ways." 8

According to British philosopher Thomas Carlyle (1795-1881), Islam is full of equality, humanism, compassion, brotherhood, and equality. ${ }^{9}$ When commenton Q.S. al-Baqarah [2]: 177, French law expert, Douminique Sourdel (1921-2014), said, "Islam is a religion that promotes the goodness of the social

${ }^{5}$ See Widji Saksono, Mengislamkan Tanah Jawa: Telaah atas Metode Dakwah Walisongo (Bandung: Mizan, 1995).

${ }^{6}$ Lodewijk Willem Christiaan van den Berg, Le Hadhramout les Colonies Arabes dans I'archipel Indie (Batavia: Impr, du Gouvernement, 1886); J.J. Meinsma, Serat Babad Tanah Jawr: Wiwit Saking Nabi Adam Dumugi ing Tabun 1647 (n.p.: S'Gravenhage, 1903).

${ }^{7}$ Ma'mun Mu'min, "Pluralisme dalam Kehidupan Pemeluk Beda Agama: Studi Kasus di Desa Rahtawu Kabupaten Kudus”, Dissertation, UIN Sunan Kalijaga Yogyakarta, 2012.

${ }^{8}$ De Lacy O’Leary, Islam at the Crossroads (London: Luzac, 1923); Clifford Geertz, The Religion of Java (Jakarta: Pustaka Jaya, 1981); Denys Lombard, Nusa Jawa: Silang Budaya Batas-batas Pembaratan (Jakarta: Gramedia, 1999); Hiroko Hirokoshi, Kyai dan Perubahan Sosial (Jakarta: P3M, 1987); Masroer Ch. Jb., The History of Java (Yogyakarta: Ar-Ruzz, 2004).

${ }^{9}$ Thomas Carlyle, al-Abthal, 80; Alice Chandler, "Carlyle and the Medievalism of the North", Medievalism in the Modern World, Essays in Honour of Leslie J. Workman, ed. Richard Utz and Tom Shippey (Turnhout: Brepols, 1998), 190. 
environment. The realization of the Qur'an and the hadith as well as the source of God's message that reveals the continuity of goodness in the world." 10

Adam Spencer Metz (born 1969), ${ }^{11}$ says, "The existence of Christians in the midst of the Muslims is due to the emergence of tolerance, coexistence and tolerance, which is unknown in Europe." According to Dutch historians such as Lodewijk Willem Christiaan van den Berg (1845-1927), H.J. de Graaf (1641-1673), Theodore G.Th. Pigeud (1899-1988), Merle Calvin Ricklefs (born 1943), ${ }^{12}$ and Martin van Bruinessen (born 1946), ${ }^{13}$ responded positively to the preaching of Walisongo. According to them, da'wah was conducted tolerantly and accultrated with Java culture, as embodied in the form of buildings mosque and salvation ceremony (selametan).

Today, however, there are some Muslims committing terror, violence and killing innocent people in the name of jihad and da'wah ${ }^{14}$ such as Doctor Azhari (1957-2005), Imam Samudra (1969-2008), Noordin Muhammad Top (1968-2009), ${ }^{15}$ and Abu Wardah Santoso in Poso. ${ }^{16}$ In return, many Muslims in Europe and America are intimidated and treated unfairly.

${ }^{10}$ Martin van Bruinessen, NU Tradisi: Relasi-relasi Kuasa, Pencarian Wacana Baru, Pencarian Wacana Baru (Yogyakarta: LKiS dan Pustaka Pelajar, 2012).

${ }^{11}$ Adam Metz, Renaissance des Islam, trans. Khuda Bukhsh (Kairo: n.p., 1957), 161; Armand Abel, "Spanyol: Perpecahan dalam Negeri", Gustave Von Grunebaum (ed.), Islam, Kesatuan dalam Keragaman (Jakarta: Yayasan Penghidmatan, 1983), 244-245.

${ }^{12}$ H.J. de Graaf, et al., Cina Muslim di Jawa Abad XV dan XVI: antara Historisitas dan Mitos (Yogyakarta: Tiara Wacana, 1997).

${ }^{13}$ Martin van Bruinessen, NU Tradisi: Relasi-relasi Kuasa, Pencarian Wacana Baru (Yogyakarta: LKiS, 2008); Martin van Bruinessen, Tarekat Naqsyabandiyah di Indonesia (Bandung: Mizan, 1996); Martin van Bruinessen, Kitab Kuning, Pesantren, dan Tarekat: Tradisi-tradisi Islam di Indonesia (Bandung: Mizan, 1995).

${ }^{14}$ Zulfi Mubarok, "Fenomena Terorisme di Indonesia: Kajian Aspek Teologi, Ideologi, dan Gerakan”, SALAM, Vol. 15, No. 2, Desember 2012, 249-250.

${ }^{15}$ Luh Ashari Sumardewi, Upaya Indonesia dalam Memberantas Terorisme di Era Susilo Bambang Yudhoyono (Denpasar Bali: Universitas Udayana, 2012), 4-8.

${ }^{16}$ Abu Wardah Santoso, "Movement and Its Network in Mujahidin Indonesia Timur (MIT)", Republika.com, April 3, 2017, Sulawesi.com, September 14, 2016. 
In response of that fact, the Chairman of PBNU Prof. Dr. K.H. Said Aqil Siradj (born 1953) at the Welcoming Ramadan Istighosah ceremony and the Opening of national conference of NU Scholars, on Sunday, June 14, 2015 at Istiqlal Mosque, offered Islam Nusantara. ${ }^{17}$ This term became the NU's $33^{\text {rd }}$ Congressional Theme on August 1-5, 2015 in Jombang, East Java, namely Affirming Islam Nusantara for Civilization of Indonesia and the World. ${ }^{18}$

According to Prof. Dr. K.H. Said Aqil Siradj (born 1953), Islam Nusantara is Islam with cultural approach, not rigid and hard doctrine, preserving and respecting local culture, as did by Walisongo and NU scholars. Islam Nusantara has friendly character, anti radical, inclusive, and tolerant. ${ }^{19}$ According to Rais Aam PBNU, K.H. Musthofa Bisri (born 1944), there is humanitarian crisis currenly caused by the dishonest act of people who use in the name of Islam. Thus the world asks, "Where is Islam that spreads grace and humanity?" Islam Nusantara is the answer of humanitarian crisis that is engulfing the Islamic world. Islam Nusantara is the solution for the creation of a harmonious world civilization. ${ }^{20}$

The concept of Islamic Nusantara has been established since August 2014 by Ali Masykur Musa (born 1962) through his book Membumikan Islam Nusantara, ${ }^{21}$ raised the pros and cons. President of the Republic of Indonesia Joko Widodo (born

${ }^{17}$ Editorial of "NU DimintaTurut JawabTantangan", Kompas, Monday, June 15, 2015, 1; M. Rikza Chamami, Islam Nusantara: Dialog Kudus dan Agama Faktual (Yogyakarta: Pustaka Zaman, 2015).

${ }^{18}$ Editorial of "NU Jadi Jembatan Peradaban", Kompas, Monday, Agustus 2, 2015, 1; Akhmad Sahal dan Munawir Aziz (ed.), Islam Nusantara: dari Ushul Fiqh hingga Masalah Kebangsaan (Bandung: Mizan, 2015).

${ }^{19}$ Report of BBC Indonesia journalist, Heyder Affanby, Editorial "Polemik di Balik Istilah Islam Nusantara”, Juni 15, 2015.

${ }^{20}$ Presented at the opening of NU's $33^{\text {rd }}$ Congress at Jombang Square, East Java on Saturday, August 1, 2015.

${ }^{21}$ Ali Masykur Musa, Membumikan Islam Nusantara: Respon Islam Terbadap Isu-isu Aktual (Jakarta: Serambi Ilmu Semesta, 2014). 
1961) in his speech at the National Conference of NU Scholars stated that he fully supports to the Islamic Nusantara model as form of moderate Islam. Azyumardi Azra (born 1955) and Komarudin Hidayat (born 1953) welcomed this idea. ${ }^{22}$ Chairman of the MUI (Indonesia Scholars Association) K.H. Cholil Ridwan (born 1947) advised the concept of Islam Nusantara not exaggerated, worried about shrinking Islam itself.. ${ }^{23}$ Chairman of PP Muhammadiyah, Prof. Dr. Din Syamsuddin (born 1958), offered a concerted Islamic concept, delivered in the $47^{\text {th }}$ Muhammadiyah Congress in Makassar, on 03-07 August 2015. Hizbut Tahrir Indonesia through its spokesman, Ismail Yusanto, questioned Islam Nusantara that contrasted with Middle Eastern Islam. ${ }^{24}$ FPI figure, Habib Muhammad Rizieq Shihab (born 1965), strongly refused and called Jemaah Islam Nusantara (JIN) as misguided and misleading. ${ }^{25}$

Regardless of the pros and cons, the concept of Islamic Nusantara is a fundamental theological problem and have to found its explanation explicitly in religious life of this modern era, especially if associated with the rise of terrorism phenomenon in Indonesia and the world evenmore interesting if it is associated with the role of NU scholars that were clearly positioned as Islamic Nusantara bearer to stem the therorism ideology in Indonesia.

Related to the background above, this research is focused on: The Challenge of IslamicNusantara to counter Terrorism Faction: Analysis Study of Islamic Nusantara Movement of NU Scholars in Central Java. This title is proposed for

\footnotetext{
${ }^{22}$ Azyumadri Azra, Islam Nusantara Adalah Islam Kita (Jakarta: Fakultas Adab dan Humaniora UIN Syarif Hidayatullah Jakarta, 2015).

${ }^{23}$ See Okezone.com, Tuesday, Agustus 4, 2015.

${ }^{24}$ Ismail Yusanto statement was delivered by BBC Indonesia, on Sunday, June 14th, 2015.

${ }^{25}$ See in Arrahmah.com, Agustus 26, 2015. Compare with Eramuslim.com, Agustus 26, 2015 and Suaraislam.com, Agustus 25, 2015.
} 
several reasons: (1) the great role of NU scholars in Java in stemming terrorism, but has not received attention; (2) the development of global terrorism, such as Santoso Network, ISIS, al-Qaeda, AQAP, Taliban Pakistan, the Taliban of Afganistan, al-Nusra Front, Boko Haram, Jemaah Islamiyah, Abu Sayyaf, and Lashker e-Taiba; (3) NU scholars and NU citizens fought for harmonious, pluralist and inclusive life; ${ }^{26}$ (4) modernity crisis, as revealed by Gilles Keppel (born 1955), ${ }^{27}$ resulted in the future shock, as illustrated by Alvin Toffler (1928-2006); ${ }^{28}$ and (5) Islam Nusantara is considered capable of stemming terrorism and violence that are spreading regionally, nationally and globally. ${ }^{29}$

\section{B. Discussion}

\section{Problems Identification and Formulation}

Study of Islam Nusantara Challenge Againt Terrorism: Analysis study of Islamic Nusantara Movement of NU scholars in Central Java, will certainly be associated with many aspects, such as: (a) historical aspects behind the emergence of Islamic Nusantara concept, that has harmonious, pluralist and inclusive character; (b) the dynamics of Islamic Nusantara development in national and global society in order to stem the idea of global terrorism in Central Java; (c) the linkage between the theological thought of NU scholars with the global discourse that was developed such pluralism and inclusivism; (d) the role of NU scholars in Central Java

${ }^{26}$ Mark R. Woodward, Islam Jawa Kesalehan Normatif versus Kebatinan,transl. HairusSalim HS, Yogyakarta, LKiS, 1999.

${ }^{27}$ Gilles Kepel, The Revenge of God: Resurgence of Islam, Christianity, and Judaism in the Modern World (Pensylvania: The Pennsylvania State University Press, 1993).

${ }^{28}$ Alvin Toffler, Kejutan Masa Depan, trans. Sri Koesdiyantinah (Jakarta: Panja Simpati, 1989; Alvin Toffler, Kejutan dan Gelombang, trans. Sri Joesdiyantinah (Jakarta: Panja Simpati, 1987).

${ }^{29}$ F.E. Jandt, Conflict Resolution Through Communication (New York: Harper and Row Publishers, 1973); Richard E. Walton, Managing Conflict, Interpersonal Dialogue and Third-Party Roles, Reading (Massachusetts: Addisonwesley Publishing, Co., 1987). 
in realizing a harmonious, pluralist, and inclusive life in the global society; (e) the response of general Central Java society to Islam Nusantara faced with global terrorism; (f) the contribution of this study to the formation of Islamic Nusantara concept or moderate Islam, Islam that has harmonious, pluralist, and inclusive character in realizing harmonious, pluralist and inclusive civilization of Indonesia and in the world.

Related to these issues, formulation of this problem research are: how to challenge Islam Nusantara in stemming terrorism, such as Islamic Nusantara movement conducted by NU scholars in Central Java? Theresearch questionsof this study as follows:

a. What aspects of historicity behind the emergence of the Islamic Nusantara concept, i.e. moderate Islam that has harmonious, pluralist and inclusive character in NU scholars in Central Java?

b. How are the dynamics of Islamic Nusantara development of NU scholars in Central Java to stemterrorism in Central Java?

c. How interrelationship between the theological ideologies of NU scholars with the development of Islam Nusantara in Central Java which is getting stronger?

d. What are the challenges faced by NU scholars in stemming terrorism in Central Java?

e. How are the society's responses to Nusantara Islamic movement by NU scholars in stemming terrorism in Central Java?

f. What are the contributions of this study to the formation of Islam Nusantara concept to realize the harmonious, pluralist and inclusive civilization of Indonesia and in the world? 


\section{Research Objectives and Advantages}

This study aims to provide an analytical understanding of socio-anthropological challenges of Islamic Nusantara Movement of NU scholars in stemming terrorism, through of view and understanding of NU scholars in Central Java. This study also expected to find the concept of Islamic Nusantara from NU scholarsperspective in Central Java for moderate Islam development.

The usefulness of this study theoretically has positive contribution to Islamic Nusantara concept development, i.e. moderate Islam that has harmonious, pluralist and inclusive character. And practically, this study is expected to find practical ways in order to stem the development of terrorism in Central Java.

\section{Islam Nusantara Concept}

The Islamic Nusantara term originally initiated by K.H. Ali Masykur Musa (born 1962) in his book Membumikan Islam Nusantara, ${ }^{30}$ then popularized by the Chairman of PBNU K.H. Said Aqil Siradj (born 1953) on the Istighosah Welcoming Ramadhan ceremony and National Conference of NU Scholars Opening, on Sunday dated June $14^{\text {th }}, 2015$ at Istiqlal Mosque Jakarta. ${ }^{31}$ President Joko Widodo fully supports the idea of Islamic Nusantara, which is full of politeness, manners, and tolerance. ${ }^{32}$ The term is increasingly popular when became NU's $33^{\text {rd }}$ Congress theme that was held on August 1-5, 2015 in Jombang, East Java,

${ }^{30}$ Ali Masykur Musa, Membumikan Islam Nusantara: Respon Islam Terbadap Isu-isu Aktual (Jakarta: Serambi Ilmu Semesta, 2014); Zainul Milal Bizawie, MasterpieceIslam Nusantara: Sanad dan Jejaring Ulama-Santri (1830-1945) (Tangerang: Pustaka Kompas, 2015).

${ }^{31}$ Editorial "NU Diminta Turut Jawab Tantangan", in Kompas, Monday, Juni 15, 2015,1 .

${ }^{32}$ Heyder Affan, "Polemik di Balik Istilah Islam Nusantara", in BBC Indonesia, Juni 15, 2015. 
namely: Affirming Islam Nusantara for Civilization of Indonesia and the World. ${ }^{33}$

According to K.H. Said Aqil Siradj (born 1953) Islam Nusantara is developed Islam with cultural approach, not rigid and not hard, preserve and respect the culture, friendly, anti-radical, inclusive and tolerant. ${ }^{34}$ According Azyumardi Azra (born 1955) Islam Nusantara is distinguishing Islam as result of interaction, contextualization, indigenization, and vernacularization of universal Islam with social, cultural, and religious practically in Indonesia. Orthodoxy of Islam Nusantara, in the field of kalam Asy'ariyah, in figh follows Shafi'i, and in tasawuf takes the model of Imam Ghozali. ${ }^{35}$

According to Ulil Abshar Abdalla (born 1967), Islam Nusantara is develops in countries under the equator which have harmonious, pluralist, and inclusive character. ${ }^{36}$ Meanwhile, according to the Ministry of Religious Affairs, Directorate General of Islamic Education, Islam Nusantara is moderate Islam, which is always objective and not radical. ${ }^{37}$ Moderate Islam is is built on a just and middle mindset (itidal and wasath). ${ }^{38}$ Moderate Islam is Islam that is adhered by the middle society (ummatan wasathiyah).

\footnotetext{
$2015,1$.

${ }^{34}$ Report of BBC Indonesia journalist, Heyder Affan with Tajuk: "Polemik di
}

${ }^{33}$ See Editorial "NU Jadi Jembatan Peradaban", Kompas, Sunday, Agustus 2, Balik Istilah Islam Nusantara”, Juni 15, 2015.

${ }^{35}$ Rosmani Ahmad, "Mengenal Azyumardi Azra dalam Pemikiran Islam”, Jurnal Analyitica Islamica, Volume 2, Issue 2, 2013, 352-370; Beritasatu.com, Wednesday, Juli 8, 2015; Suara Pembaruan, Wednesday, Juli 8, 2015, Editorial of Islam Nusantara Adalah Islam Toleran, 1. Khabibi Muhammad Luthfi, "Islam Nusantara: Relasi Islam dan Budaya Lokal”, Jurnal Shahih, Volume 1, Issue 1, Januari-Juni 2016, 8.

${ }^{36}$ Ulil Abshar Abdalla, "Memperbincangkan Islam Arab dan Islam Nusantara", paper of STAIN Kudus New Students Studium General, Tuesday, September 1, 2015.

${ }^{37}$ Letter of Islamic Higher Education Director, Number: Dj.I/Dt.I.IV/1/ PP.00.9/3012/2015 on Notification of Islam Nusantara aid, Agustus 19, 2015.

${ }^{38}$ Suwito, Abdul Ghani Abdullah, et al., Pengembang Islam dan Budaya Moderat (Jakarta: Young Prgressive Muslim Publishing, 2016). 
According to K.H. Hasyim Muzadi (1944-2017), ummatan wasathan is Muslim who always tawasuth (looking for middle ground) and $i$ tidal (always fair and balanced), balancing between faith and tolerance. Faith without tolerance leads to exclusivism and extremism, while democracy and tolerance without faith leads to confusion and chaos. With tolerance, ummatan wasathan will live together peacefully in one society with same and other religion people. For example, NU as the largest Islamic Religious Organization in the world could harmonious co-exist with other religious organizations in the world. ${ }^{39}$

According to Muhammad Tholhah Hasan (born 1938), NU as Islamic Religious Organization (jam'iyah) and community (jama'ab), has moderate caracter and socio-cultural (tawassuth), tolerant (tasamub), and harmony (tawazun)..$^{40}$ Muhammad Imarah (born 1931) in his book Ma'rakah al-Mustalahayat baina al-Garb wa al-Islam, reviews the moderate terminology (al-wasatiyah) from the Islamic view and confronts it with western terminology. According to Imarah, moderate Islam consept is a term that has a very important and noble meaning, although in practice often misunderstood. Moderate in Islam is not merely a "third and new attitude", but also a method (manhaj) that mediates two opposing extremes, by rejecting the exaggeration of one party to the end of favoring one of the two poles to the contrary. Moderate in Islam is a principle which necessitates every Muslim to embrace and combine various elements that can be synergized in a harmony, not mutually hostile

${ }^{39}$ Muhammad Makmun Rasyid, "Islam Rabmatan lil 'Alamin Perspektif K.H. Hasyim Muzadi”, in Episteme: Jurnal Pengembangan Ilmu Keislaman, Volume 11, Issue 1, 2016, 94-116.

${ }^{40}$ Muhammad Tholhah Hasan, Ablussunah wal Jama'ah (Jakarta: Lantabora Press, 2005), 3-4. 
to the two opposite poles, but indeed interrelations of various elements. ${ }^{41}$

Furthermore, according to Imarah, the concept of Isathiyah in Islam is a method (manhaj) that combines the spirit and body, the world and the hereafter, religion and country, the subject and object, the real and ideal, goals and ways, mind ('aql) and naql, local and global, ijtihad and taqlid, religion and science, general and special, sacral and profane, das sein and das sollen. Moderate muslims can be formulated who stand between two opposing extremities, not side with one side, and are on the line or "third way" by offering a comprehensive, balanced, and fair solution. ${ }^{42}$

\section{Terrorism Concept}

Experts differ in terrorism definitionbecause see from action, character, its form and problem root perspectives. ${ }^{43}$ Etymologically, terrorism comes from the word "terrere" means making trembling, vibrating or acts that cause horror. Terrorismis often used as negative stigma to wipe a group or nation against the hegemony of power. In general, terrorism has a sensitive connotation concept because it resulted in innocent civilian victims. ${ }^{44}$

In terminology, the definition of terrorism stems from the assumption that violence acts could be an alternative problem solving, especially concerning political violence, justifiable and unjustifiable. Unjustifiable violence is referred

${ }^{41}$ Muhammad Imarah, Perang Terminologi Islam versus Barat (Jakarta: Logos, 1989), 267-269.

${ }^{42}$ Muhammad Imarah, Perang Terminologi Islam versus Barat (Jakarta: Logos, 1989),

${ }^{43}$ Tore Bjorgo (ed.), Root Causes of Terrorism: Myths, Reality, and Ways Forward (London and New York: Routledge, 2005), 1.

${ }^{44}$ Andriyanto Seno Adji, Terorisme dan HAM dalam Terorisme: Tragedi Umat Manusia (Jakarta: A.C. Kaligis dan Associates, 2001), 17. 
to act of terror.So terrorism is the idea that the use of violent means and others fear is legal way for achieving the goal.

According to T.P. Thornton, ${ }^{45}$ terrorism is symbolic act designed to political policy influence and behavior in extraordinary ways, the use and threat of violence. Terrorism can be distinguished into two categories: (a) enforcement terrorism exercised by the authorities to suppress challenges to their powers; (b) agitation terror, terror perpetuating the established order and then mastering a particular political order.

According to Webster's New World College Dictionary, terrorism is the use of force or threats to demoralize, intimidate, and subjugate. The doctrine distinguishes terrorism into two definitions: the definition of terrorist acts and terrorism actor. According to most experts, actions that belong to terrorism are acts that have three main elements: (a) violence; (b) political objectives; (c) terror (intended audience). ${ }^{46}$

Theword terror according to Alex Peter Schmid and Albert J. Jongman in his book "Political Terrorism: a New Guide to Actors, Authors, Concept, Data Bases" (1974) and Brian Jenkins in the book "Terrorism and Beyond" (1985), define terror as act to create fear, horror, and cruelty by person or group. Terroristgroups use violence to inflict fear on non-combatants in illegitimate ways to achieve political goal.

According to M.B. Ali and T. Deli, ${ }^{47}$ terror means act of cruel or arbitrary,while terrorism means acts of terror. According

${ }^{45}$ T.P. Thornton, Terror as a Weapon of Political Agitation (New York: Free Press of Glencoe, 1964).

${ }^{46}$ Willey, Webster's New World College Dictionary (Indiana, Indianapolis: In and Chichester, 2005).

${ }^{47}$ M.B. Ali dan T. Deli, Kamus Lengkap Babasa Indonesia (Bandung: Penabur Ilmu, 2000). 
to Anton Tabah, ${ }^{48}$ terror is an adjective that describes extraordinary fear, no security guarantees (security), no safety guarantees (safety) and no legal guarantee (legality). The extraordinary fear passes through boundaries, space and time. ${ }^{49}$

From these definitions could be concluded that terrorism is an organized violence that places violence as consciousness, a method of thinking as well as a means of achieving a goal with its characteristics as follows: (a) the existence of plan to carry out the action; (b) conducted by particular group; (c) take casualties from civil society in order to intimidate the authorities; (d) be made to achieve the fulfillment of certain purposes of the perpetrator, which be social, political or religious motivation. ${ }^{50}$ Thus, an action can be categorized as terrorism with the following restrictions: (a) there is an element of violence; (b) there is a motive for crime, such as ideological, political, and hate motivation; (c) there is impact of act, such as psychological, economic, disintegration, or vacum of power. $^{51}$

According to Tore Bjorgo, ${ }^{52}$ there are two factors that cause terrorism: (a) factors that provide conditions in the long run and form terrorism (preconditions of terrorism); (b) specific phenomena that directly precede the occurrence of terrorism ( precipitants of terrorism). Both of these factors by Bjorgo are divided into four levels: (a) structural causes; (b) causes of facilitator or accelerator; (c) motivational causes; 2005), vii.

${ }^{48}$ Anton Tabah, Menangani Kasus-kasus Bom di Indonesia (Jakarta: Cyntia Press,

${ }^{49}$ S. Endriyono, Terorisme: Ancaman Sepanjang Masa (Semarang: Media Agung Persada, 2005). 2008).

${ }^{50}$ Asep Adisaputra, Korban Kejahatan (Jakarta: Fisipol Universitas Indonesia,

${ }^{51}$ William G. Cunningham, et al., Terorisme: Consepts, Causes, and Conflic Resolution (Virginia: Defense Threat Reduction Agency Fort Belvoir, 2003), 7-11.

${ }^{52}$ Tore Bjorg (ed.), Root Causes of Terrorism: Myths, Reality, and Ways Forward (London and New York: Routledge, 2005), 1. 
(d) movement cause triggers. According to Azra, the cause of terrorism are: (a) psychological; (b) political; (c) economic; (d) religion; (e) culture. ${ }^{53}$

According to Wahid and Asraf, there are three motives of terrorism movement in Indonesia, are: (a) economic motivation; (b) social motivation; (c) ideological motivation. In fact these three motivations sometimes support each other and become motivation simultaneously. ${ }^{54}$

From the perpetrators view there are two forms of terrorism. First, physical terrorism, activities attract people attention such as explosions, bombings, kidnappings, suicide bombings, and piracy. Second, ideological terrorism, the sources of physical terrorism that comes from the ideological impulse of the perpetrators, both Muslims or non-Muslims. ${ }^{55}$

\section{Research Methods}

This type of study is field research, research that has natural characteristics and its field work is descriptive qualitative. ${ }^{56}$ Qualitative research is a research in the social and cultural sciences that is fundamentally dependent on human observation within its own region and relates to that person in the language and terminology. ${ }^{57}$ This study also uses a qualitative descriptive approach, by collecting data as much as possible

${ }^{53}$ Azyumardi Azra, "Jihad dan Terorisme: Konsep dan Perkembangan Historis", Jurnal Studia Islamika, $4^{\text {th }}$ Edition, April-June 1994.

${ }^{54}$ Abdul Wahid, Kejabatan Terorisme (Bandung: Refika Aditama, 2004), 33; Muhammad Asraf, Islam Lunak Islam Radikal (Surabaya: Pusat Studi Demokrasi dan HAM, 2003), 18.

${ }^{55}$ Zulkarnain M. Sunusi, Antara Jihad dan Terorisme (Makassar: Pustaka asSunnah, 2011), 132-133.

${ }^{56}$ Benard Russell, Research Methods in Antropology (London-New Delhi: SAGE Publications, 1994), 65.

${ }^{57}$ Lexy J. Moleong, Metodologi Penelitian Kualitatif, Bandung, Remaja Rosdakarya, 2001, p.3. 
about the supporting factors and analyze these factors to look for their role. $^{58}$

There are two sources of data, primary and secondary data. Primary data is obtained directly from the research subject, ${ }^{59}$ i.e. data about the Islam Nusantara movement by NU scholars in Central Java to stem the idea of terorisme. Secondary data is obtained from books, magazines, internet, and others as a sources of support. ${ }^{60}$

Theinformants are determined by the concept of James P. Spradley ${ }^{61}$ and Benard Russell, ${ }^{62}$ whom understand the sociocultural conditions needed. Key informants of this study, such as K.H. Maimun Zubair (born 1928), K.H. Mustofa Bisri (born 1944), K.H. Mu'adz Mahfudz (born 1950), K.H. Sya'roni Ahmadi (born 1932), Prof. Dr. K.H. Abdul Hadi Ahmuza, MA (born 1954), K.H. Dimyati Rois (born 1940s), K.H. Muhammad Hanif Muslich, Lc., and Dr. K.H. Chariri Shofa, M.Ag. (born, 1950s).

This study uses inductive analysis, ie analysis with the method of thinking that depart from facts and concrete events, then from those evidences are drawn general conclusion. ${ }^{63}$

\section{Result}

This study was titled "The Challenges of Islam Nusantara Stemming the Fear of Terrorism: the Analysis

${ }^{58}$ Suharsimi Arikunto, Prosedur Penelitian Suatu Pendekatan Praktik, Jakarta, Rineka Cipta, 2007, p.108.

${ }^{59}$ Syaifuddin Azwar, Metode Penelitian, Yogyakarta: Pustaka Pelajaran, 2000, p.91.

${ }^{60}$ Sutrisno Hadi, Metodologi Research, Yogyakarta, Fakultas Psikologi UGM Yogyakarta, 1987, p.10.

${ }^{61}$ James P. Spradley, Metode Etnografi, terj. Yogyakarta, Tiara Wacana, 1987, p.61.

${ }^{62}$ Benard Russell, Research Methods in Antropology, London-New Delhi, SAGE Publications, 1994, p.166.

${ }^{63}$ Suharsimi Arikunto, Prosedur Penelitian Suatu Pendekatan Praktik, Jakarta, Rineka Cipta, 2007, p.202 
Study of Islamic Nusantara Movement by NU Scholars in Central Java". The findings can be summarized as follows:

a. Historical aspects behind the emergence of the Islamic Nusantara concept, i.e. moderate Islam that has harmonious, pluralist, and inclusive character among NU scholars in Central Java.

1) Historically, the existence of tantularism and tantricana philosophy was developed by $\mathrm{Mpu}$ Tantular was believed still be an imprint and influence the mindset and understanding of the Muslim community in Java and NU scholars in Central Java in developing the Islamic Nusantara concept, which absorbed the core of each value system religious teachings in Indonesia.

2) Historically, the existence of the kejawen philosophy that developed in Javanese society generally and the NU Muslim community in Central Java particularly, was believed still affect the mindset and lifestyle of Muslim community in Java in shaping harmonious and pluralist society, as form of Islam Nusantara.

3) Historically, the philosophy of Walisongo teachings, which preaches the values of harmonious and pluralist, were conducted by Syekh Ja'far Shodiq, Raden Umar Said, Sunan Kalijaga, and other Walisongo who put forward da'wah in harmony by integrating the values of Islamic teachings with local traditions and cultures that have been developed in Central Java.

4) Historically, the existence of Islamic da'wah philosophy which was submitted by NU scholars of Central Java which promote wisdom and mavidah hasanah methods, and combining Islamic values 
with established local traditions and cultures. So the tradition that lives in the NU Muslim community in Central Java is pluralist, harmonious and inclusive tradition, that became the main core of of Islamic Nusantara development.

b. The dynamics of Islamic Nusantara development among NU scholars in Central Java for global community in stemming terrorism in Central Java.

1) In the first period, from the seventh to the seventeenth century (7-17 century), when Islam entered to Indonesia, this newly developed religion had to deal with the Hindu-Buddhist that had already existed. At that time (the VII and VIII) Islam entered to Indonesiafor economic or trade purpose. In this period muslim merchants came to Indonesia merely for trading. But in its development has implications for Islamic village formation centralized around the coastal port of West Aceh to the northern coast of Java (Pantura).

2) In the second period, from the $X$ to XIII AD, Islam entered to Indonesia not only for economic purpose, but also accompanied by motivation of Islamic da'wah. The intensity of muslim merchants and scholars influx was greater. During this period there were large Moslem community in every major port, especially along the north coast of Java, from Cirebon in West Java to Banyuwangi in East Java.

3) In the third period, from the XIII to XVI AD, Islam entered for economic and Islamic da'wah motives, and also accompanied by political purpose. In the third period, from the XIII to XVI AD, Islam entered for economic and Islamic da'wah motives, and also accompanied by political purpose. 
In this period the merchants and the scholars not only take of business issues and Islamic da'wah care, but also tried to establish a country that can accommodate whole muslims interests in nusantara. The participation and influence of the Ottoman Empire in da'wah development and Islamic empire establishment in nusantara was very large.

4) In the fourth period, from the sixteenth to the seventeenth centuries AD (XVI-XVII), the Islamic empire in nusantara fell into colonialism bond that began with the entry of Portuguese, Dutch Colonial, and Japanese Occupation. Practically during this period the development of Islam Nusantara faced heavy obstacle up. In this period madrasa and boarding schools established by NU scholars in Central Java were instrumental in the development of Islamic Nusantara.

5) The fifth period, around the twentieth century to the present, Muslims in nusantara have freed themselves from the Dutch colonization and occupation of Japan, and fill the independence with various actions and activities in order to foster Islam Nusantara. The existence of madrassas and boarding schools when the colonial era faced various obstacles, in this period freely continue the development of Islam Nusantara.

c. The linkage between the theological ideology of the NU scholars Central Java and the development of Islamic Nusantara in Central Java.

1) The theological ideology of NU scholars in Central Java originated from the teachings of Prophet Muhammad SAW, the companions, the tabi'in, tabi'it tabi'in, and the salafus salih. The core of the teaching 
that was absorbed in this early generation was Islam as rabmatan li al-'alamin.

2) Islam rabmatan li al-'alamin developed by the NU scholars in Central Java was the Ahlussunnah wal Jama'ah, which in fiqib field followed one of the four mazhab Syafi'i, Maliki, Hanafi, or Hanbali. In the matter of kalam refers to Imam Asy'ari or Imam Maturidi opinion, and in the matter of Sufism based on Imam Gazali.

3) The theology of Ahlussunnah wal Jama'ah is the foundation of Islam Nusantara formation that was developed by the Walisongo inIndonesia. All matter about fiqih, kalam and tasawnf refer to the provisions as required in Ahlussunnah wal Jama'ah.

4) In 1926, theology of Ahlussunnah wal Jama'ah, metamorphosed in the form of NU. At the beginning of its formation aim to unite all muslim in Nusantara, against Dutch colonialism and seize their independence, minimize western modernism influences, and empower Muslims from various backwardness, such as underdevelopment of science, economy, politics, and culture.

5) Ahlussunnah wal Jama'ah as the theological ideology of NU scholars in Central Java, became the basis of Islam Nusantara or moderate Islam formation, that has harmonious, pluralist and inclusive caracter. Islam that is capable of realizing the civilization of harmony, pluralist, and inclusive and the world. 
d. The challengesare faced by NU scholars of Central Java in stemming terrorism in Central Java.

1) During colonialism challenges came from the colonizers, such as Portuguese, Dutch Colonial, and Japanese Occupation.

2) Post-independence challenges come from Islamic fundamentalists who impose narrow and rigid understanding of religion, they argued only their opinions as true and others wrong.

3) Post-reform challenges come from terrorists, such as Doctor Azhari, Imam Samudra, Noordin Muhammad Top, Abu Wardah or Santoso, and other groups.

4) Islamic educational institutions, such as madrassas and boarding schools that in their curriculum materials and methods of learning teach exclusive learning methods will form many terrorists.

5) The development of global terrorism occurring in the Middle East, Africa, Europe, and America have strong influence terrorism development in Indonesia, which poses challenge for NU scholars in stemming terrorism in Central Java.

6) Nowadays the challenge comes from Hizbut Tahrir Indonesia (HTI) and Front Pembela Islam (FPI) who disagree with the Islamic Nusantara concept and expressly rejects it.

e. The public response to Islam Nusantara developed by NU scholars in stemming the idea of terrorism in Central Java.

1) Negative responses certainly come from terrorists, fundamentalists, exclusive Islamic educational institutions, exclusive religious groups, and 
those who were disturbed by Islam Nusantara development.

2) Definitely a positive response to the development of Islam Nusantara came from the President and Vice President of Indonesia, Minister of Religious Affairs, state officials, scholars, clerics, and people who aspire harmonious and pluralist life.

f. This research contributes to the development of Islam Nusantara or Moderate Islam concept, that has harmonious, pluralist and inclusive character which is believed to stem the national and global terrorism ideas, and realize the civilization of harmonious, pluralist and inclusive Indonesia and the world.

\section{Conclusion}

The more widespread ideology in the era of global terrorism today has become a global concern, acts of terror committed national or transnational terrorists have been bad for the creation of a harmonious world order, pluralist and inclusive. Several countries collapse in the Middle East and Africa as well as the tense conditions in Poso has been the evidence of how acts of terror committed the terrorists do not recognize tribes, nations and religions. If this trend continues, then the life of mankind and civilization of the world will be damaged. Long before understanding terrorism rampant in Indonesia and the world, the scholars Walisongo through propaganda Islamiyah has offered the concept of Islam Nusantara, the moderate Islam that can adapt to the cultural heritage at the time. Islam Nusantara or moderate Islam is essentially Islam that gave mercy to all the worlds. These efforts Walisongo scholars ulama NU followed by the next generation until now. Rampant ideology of terrorism today is of course a challenge for the NU clerics spearheading 
the development of Islam in the Indonesian archipelago. This research will find: formulation of basic normatively and historicity and the philosophical concept of Islam Nusantara, formulated the concept of Islam Nusantara in the perspective of scholars Walisongo and ulama NU in Central Java, the dynamics of socio-political development of Islam Nusantara in Central Java from time to time, the public response in Central Java to the development of Islam Nusantara, and the contribution of Islam Nusantara in a moderate Islam that can create harmony, pluralist and inclusive in order peaceful world civilization. 


\section{REFERENCES}

Abdalla, Ulil Abshar. "Memperbincangkan Islam Arab dan Islam Nusantara", paper of STAIN Kudus New Students Studium General, Tuesday, September 1, 2015.

Abdullah, Rachmad. Walisongo: Gelora Dakwah dan Jihad di Tanah Jawa (1404-1482 M). Solo: Penerbit Al-Wafi, 2015.

Abel, Armand. "Spanyol: Perpecahan dalam Negeri", Gustave Von Grunebaum (ed.), Islam, Kesatuan dalam Keragaman. Jakarta: Yayasan Penghidmatan, 1983.

Adisaputra, Asep. Korban Kejahatan. Jakarta: Fisipol Universitas Indonesia, 2008.

Adji, Andriyanto Seno. Terorisme dan HAM dalam Terorisme: Tragedi Umat Manusia. Jakarta: A.C. Kaligis dan Associates, 2001.

Affan, Heyder. "Polemik di Balik Istilah Islam Nusantara", in BBC Indonesia, Juni 15, 2015.

Ahmad, Rosmani. "Mengenal Azyumardi Azra dalam Pemikiran Islam", Jurnal Analyitica Islamica, Volume 2, Issue 2, 2013, 352-370

Akasah, Hamid and Aby Azizy (ed.), Babad Tanah Jawa: Majapabit, Demak, dan Pajang. Surabaya: Cipta Adi Grafika, 1989.

Ali, M.B. and T. Deli, Kamus Lengkap Bahasa Indonesia. Bandung: Penabur Ilmu, 2000.

Ambary, Hasan Muarif and Jacques Dumarcay. The Sultanate of Banten. Jakarta: Gramedia, 1990. 
Asraf, Muhammad. Islam Lunak Islam Radikal. Surabaya: Pusat Studi Demokrasi dan HAM, 2003.

Azra, Azyumardi. "Jihad dan Terorisme: Konsep dan Perkembangan Historis", Jurnal Studia Islamika, $4^{\text {th }}$ Edition, April-June 1994.

- Islam Nusantara Adalah Islam Kita. Jakarta: Fakultas Adab dan Humaniora UIN Syarif Hidayatullah Jakarta, 2015.

Bizawie, Zainul Milal. MasterpieceIslam Nusantara: Sanad dan Jejaring Ulama-Santri (1830-1945). Tangerang: Pustaka Kompas, 2015.

Bjorgo, Tore (ed.), Root Causes of Terrorism: Myths, Reality, and Ways Forward. London and New York: Routledge, 2005.

Ch. Jb., Masroer. The History of Java. Yogyakarta: Ar-Ruzz, 2004.

Chamami, M. Rikza. Islam Nusantara: Dialog Kudus dan Agama Faktual. Yogyakarta: Pustaka Zaman, 2015.

Chandler, Alice. "Carlyle and the Medievalism of the North", Medievalism in the Modern World, Essays in Honour of Leslie J. Workman, ed. Richard Utz and Tom Shippey. Turnhout: Brepols, 1998.

Cunningham, William G., et al., Terorisme: Consepts, Causes, and Conflic Resolution. Virginia: Defense Threat Reduction Agency Fort Belvoir, 2003.

de Graaf, H.J., et al., Cina Muslim di Jawa Abad XV dan XVI: antara Historisitas dan Mitos. Yogyakarta: Tiara Wacana, 1997.

de Graff, H.J., et al. Cina Muslim di Jawa Abad XV dan XVI. Yogyakarta: Tiara Wacana, 2004).

Editorial "NU Diminta Turut Jawab Tantangan", in Kompas, Monday, Juni 15, 2015. 
Editorial "NU Jadi Jembatan Peradaban", Kompas, Sunday, Agustus 2, 2015.

Editorial of "NU DimintaTurut JawabTantangan", Kompas, Monday, June 15, 2015.

Editorial of "NU Jadi Jembatan Peradaban", Kompas, Monday, Agustus 2, 2015.

Endriyono, S. Terorisme: Ancaman Sepanjang Masa. Semarang: Media Agung Persada, 2005.

Geertz, Clifford. The Religion of Java. Jakarta: Pustaka Jaya, 1981.

Hasan, Muhammad Tholhah. Ablussunah wal Jama'ah. Jakarta: Lantabora Press, 2005.

Hirokoshi, Hiroko. Kyai dan Perubahan Sosial. Jakarta: P3M, 1987.

Imarah, Muhammad. Perang Terminologi Islam versus Barat. Jakarta: Logos, 1989.

Jandt, F.E. Conflict Resolution Through Communication. New York: Harper and Row Publishers, 1973.

Kapanjani, A.R. Menyingkap Kisah Keteladanan Perjuangan Walisongo. Surabaya: Anugerah, 1992.

Kepel, Gilles. The Revenge of God: Resurgence of Islam, Christianity, and Judaism in the Modern World. Pensylvania: The Pennsylvania State University Press, 1993.

Lombard, Denys. Nusa Jawa: Silang Budaya Batas-batas Pembaratan. Jakarta: Gramedia, 1999.

Luthfi, Khabibi Muhammad. "Islam Nusantara: Relasi Islam dan Budaya Lokal", Jurnal Shabih, Volume 1, Issue 1, Januari-Juni 2016.

Meinsma, J.J. Serat Babad Tanah Jawi: Wiwit Saking Nabi Adam Dumugi Ing Tahun 1647. n.p.: S’Gravenhage, 1903. 
Metz, Adam. Renaissance des Islam, trans. Khuda Bukhsh. Kairo: n.p., 1957.

Mu'min, Ma'mun. "Pluralisme dalam Kehidupan Pemeluk Beda Agama: Studi Kasus di Desa Rahtawu Kabupaten Kudus”, Dissertation, UIN Sunan Kalijaga Yogyakarta, 2012.

Mubarok, Zulfi. "Fenomena Terorisme di Indonesia: Kajian Aspek Teologi, Ideologi, dan Gerakan", SALAM, Volume 15, Issue 2, December 2012.

Muljana, Slamet. Runtubnya Kerajaan Hindu Jawa dan Timbulnya Negara-negara Islam di Nusantara. Yogyakarta: LKiS, 2015.

Musa, Ali Masykur. Membumikan Islam Nusantara: Respon Islam Terbadap Isu-isu Aktual. Jakarta: Serambi Ilmu Semesta, 2014.

O'Leary, de Lacy. Islam at the Crossroads. London: Luzac, 1923.

Rasyid, Muhammad Makmun. "Islam Rahmatan lil 'Alamin Perspektif K.H. Hasyim Muzadi", Episteme: Jurnal Pengembangan Ilmu Keislaman, Volume 11, Issue 1, 2016.

Russell, Benard. Research Methods in Antropology. London-New Delhi: SAGE Publications, 1994.

Sahal, Akhmad and Munawir Aziz (ed.), Islam Nusantara: dari Ushul Fiqh hingga Masalah Kebangsaan. Bandung: Mizan, 2015.

Saksono, Widji. Mengislamkan Tanah Jawa: Telaah atas Metode Dakwah Walisongo. Bandung: Mizan, 1995.

Santoso, Abu Wardah. "Movement and Its Network in Mujahidin Indonesia Timur (MIT)", Republika.com, April 3, 2017. 
Sanusi, Zulkarnain M. Antara Jihad dan Terorisme. Makassar: Pustaka as-Sunnah, 2011.

Sumardewi, Luh Ashari. Upaya Indonesia dalam Memberantas Terorisme di Era Susilo Bambang Yudboyono. Denpasar Bali: Universitas Udayana, 2012.

Sunyoto, Agus. Atlas Walisongo. Jakarta: Pustaka Imam, 2012.

Suwito and Abdul Ghani Abdullah, et al., Pengembang Islam dan Budaya Moderat. Jakarta: Young Prgressive Muslim Publishing, 2016.

Syamsuddin, Zainal Abidin bin. Fakta Baru Walisongo. Jakarta: Pustaka Imam Bonjol, 2016.

Tabah, Anton. Menangani Kasus-kasus Bom di Indonesia. Jakarta: Cyntia Press, 2005.

Thornton, T.P. Terror as a Weapon of Political Agitation. New York: Free Press of Glencoe, 1964.

Toffler, Alvin. Kejutan Masa Depan, trans. Sri Koesdiyantinah. Jakarta: Panja Simpati, 1989.

van Bruinessen, Martin. Kitab Kuning, Pesantren, dan Tarekat: Tradisi-tradisi Islam di Indonesia. Bandung: Mizan, 1995. . NU Tradisi: Relasi-relasi Kuasa, Pencarian Wacana Baru. Yogyakarta: LKiS dan Pustaka Pelajar, 2012.

_. Tarekat Naqsyabandiyah di Indonesia. Bandung: Mizan, 1996.

van den Berg, Lodewijk Willem Christiaan. Le Hadhramout at les Colonies ArabesdansI'archipeiIndien. Batavia: Impr du Gouvement, 1886.

_. Le Hadhramout les Colonies Arabes dans I'archipel Indie. Batavia: Impr du Gouvernement, 1886.

Wahid, Abdul. Kejahatan Terorisme. Bandung: Refika Aditama, 2004. 
Walton, Richard E. Managing Conflict, Interpersonal Dialogue and Third-Party Roles, Reading. Massachusetts: Addisonwesley Publishing, Co., 1987.

Willey. Webster's New World College Dictionary. Indiana, Indianapolis: In and Chichester, 2005.

Woodward, Mark R. Islam Jawa Kesalehan Normatif versus Kebatinan,transl. HairusSalim HS. Yogyakarta: LKiS, 1999. 
Ma'mun Mu'min dan Fathul Mufid

Halaman Ini Tidak Sengaja Untuk Dikosongkan. 